\title{
Free Speech and the Visage Culturel: \\ Canadian and American Perspectives \\ on Pop Culture Discrimination
}

\author{
Ian Slotin
}

Canada as a separate but dominated country has done about as well under the U.S. as women, worldwide, have done under men; about the only position they've ever adopted toward us, country to country, has been the missionary position, and we were not on top. I guess that's why the national wisdom vis-à-vis Them has so often taken the form of lying still, keeping your mouth shut, and pretending you like it.... Our national animal is the beaver,... noted for its industry and its co-operative spirit. In medieval bestiaries it is also noted for its habit, when frightened, of biting off its own testicles and offering them to its pursuer. I hope we are not succumbing to some form of that impulse.

- Canadian writer Margaret Atwood on capitulating to the inundation of American popular culture

[T]elevision is just another appliance. It's a toaster with pictures.

- Former FCC Chair Mark Fowler ${ }^{2}$

There is a substantial governmental and First Amendment interest in promoting a diversity of views provided through multiple technology media.

-U.S. Congress, Cable Television Consumer Protection and Competition Act of $1992^{3}$

1. ROBERT Fulford, BeSt SEAT IN THE HOUSE 188 (1988) (quoting from Atwood's testimony before a parliamentary committee on free trade).

2. Bernard D. Nossiter, Licenses To Coin Money: The F.C.C.'s Big Giveaway Show, 240 NATION 402, 402 (1985) (quoting Mark Fowler).

3. Cable Television Consumer Protection and Competition Act of 1992, Pub. L. No. 102-385, \$2(a)(6), 106 Stat. 1460, 1461 (codified in scattered sections of 47 U.S.C.).

2289 


\section{INTRODUCTION}

"Culture," it is said, "is one of the two or three most complicated words in the English language." 4 The recurring confrontations between Canada and the United States over works of popular culture are a vivid illustration of culture's complexity. ${ }^{5}$ To Canadians, pop culture works are a space for Canadians to express their views, experiences, and aspirations. Canadians view that cultural space as integral to nourishing and preserving a national identity that consciously defines itself by its differences from the United States. Margaret Atwood's statement, quoted above, expresses an extreme version of the Canadian view that the deluge of American cultural works in Canada is a direct and serious threat to Canadian cultural industries and, by extension, to Canadian identity and sovereignty. ${ }^{6}$ For Americans, whose perspective is shaped by a history of liberal markets and an ingrained suspicion of governmental measures that limit speech, the asserted connection between protecting popular culture and Canadian sovereignty is hard to swallow. Mark Fowler's statement likening television to "a toaster with pictures" illustrates the most extreme American position on works of popular culture - that the market, not the government, should dictate how and whether these products are disseminated. ${ }^{\text {. While }}$ Americans often treat the notion of a distinct Canadian national identity with less respect than it deserves, there is a reciprocal failure by many Canadians to understand the important roles that free speech and free markets have in the lives of U.S. citizens.

4. RAYMOND WILLIAMS, KEYWORDS: A VOCABULARY OF CULTURE AND SOCIETY 87 (1983). I do not mean "culture" in the anthropological sense of "a given people's particular set of preferences, predispositions, attitudes, objectives, goals; its particular way of perceiving, feeling, thinking, and reacting to objective reality." Raymond Gagné, French Canada: The Interrelationship Between Culture, Language, and Personality, in CANADIAN HISTORY SINCE CONFEDERATION 521, 525-26 (Bruce Hodgins \& Robert Page eds., 1972). Rather, I am referring to "the works and practices of intellectual and especially artistic activity." WILLIAMS, supra, at 90.

5. The debate is rarely over "high" culture-painting, sculpture, literature, opera, and the like. It is over mass-produced "popular" culture-film, television, music, mass-market books, and mass-market periodicals. This is where the money is truly at stake on both sides. Oliver R. Goodenough, Defending the Imaginary to the Death? Free Trade. National Identity, and Canada's Cultural Preoccupation, I5 ARIZ. J. INT'L \& COMP. L. 203, 210 (1998). In this Note, all references to culture should be understood to be referring to this contentious "pop culture" subset.

6. For a more systematic elaboration of that argument, see FRANKLYN GRIFFITHS, STRONG AND FREE: CANADA AND THE NEW SOVEREIGNTY (1996), which argues that a strong culture is essential to Canadian national security; and infra text accompanying notes 58-63.

7. Mark Fowler's toaster comment reflected the general temperament of the FCC during the Reagan Administration. It was at that time that the FCC repealed the "faimess doctrine," a measure that imposed restrictions on a broadcaster's speech in the intercst of increasing the diversity of views expressed on broadcast television. Cass R. Sunstein, Television and the Public Interest, 88 CAL. L. REV. 499, 507 (2000). The U.S. Supreme Court had upheld those rules sixteen years earlier in Red Lion Broadcasting Co. v. FCC, 395 U.S. 367, 394 (1969). 
Over the past century, Canadian policies attempting to mitigate the alleged harms of an inundation of American pop culture products have assumed two forms: those that aim to promote indigenous Canadian mass culture through subsidies, and those that aim to protect existing Canadian cultural industries by using tariff barriers and Canadian content rules. The protective policies have drawn the ire of the United States for two related reasons. First, the American government regards such measures as primarily economic-not cultural-protectionism that violates Canada's international trade obligations. Second, because Canada's protective policies have the purpose and effect of restricting speech on the basis of content, Americans view the Canadian government's intervention in that area as particularly invidious.

This Note examines the competing Canadian and American perspectives on protective regulations of magazines and cable television, with an emphasis on the constitutional freedom of expression jurisprudence of each country. I observe that Canadian and American free expression principles coincide with each nation's political position on content-based ${ }^{8}$ regulation of popular culture. I also observe, however, that despite their continual hostility toward Canadian protective regulations, American lawmakers themselves employ arguably content-based rules to protect local, distinct culture when those voices are threatened by outside influences. Praising the cultural and educational value of local broadcast television stations, Congress passed the Cable Television Consumer Protection and Competition Act of 1992, ${ }^{9}$ requiring cable providers to carry local broadcast signals. Though the United States Supreme Court held that Congress had a content-neutral objective, I argue that Congress's actual intention was analogous to the Canadian drive to protect the idiosyncratic conversations of a small community from an onslaught of influences of a much larger one. Thus, while arguing abroad that popular culture works should be treated merely as ordinary commodities, the United States relies on a conceit of content-neutrality at home to privilege local culture.

The divergence between America's international position on culture and its protective measures at home exposes the myth of the United States as a paragon of cultural free trade. These contrary positions ought to be reconciled. Rather than adopting the extreme position that pop culture goods are ordinary commodities. the United States Trade Representative

8. Except where indicated otherwise, I adopt the American connotations of "content-based" and "content-neutral" throughout. Generally, if one must consider the meaning of what a person says to decide whether she has violated a rule, that rule is content-based. A rule that restricts expression without regard to the content expressed is content-neutral. E.g., Tumer Broad. Sys., Inc. v. FCC, 512 U.S. 622, 643 (1994). For an explanation of the Canadian concept of contentneutrality, see infra text accompanying notes 92-96.

9. Cable Television Consumer Protection and Competition Act of 1992, Pub. L. No. 102-385, 106 Stat. 1460 (codified in scattered sections of 47 U.S.C.). 
(USTR) $^{10}$ should acknowledge the special value Americans themselves ascribe to pop culture works and be more willing to accommodate the efforts of other nations to preserve their own cultural industries.

I present an overview of the Canadian content-based protective measures for magazines and television in Part II. Part III explores the Canadian and American national myths that underlie those nations' competing visions of the role and importance of popular culture. Canadian courts have never considered whether Canada's content-based pop culture discrimination infringes the guarantee of freedom of expression in the Canadian Charter of Rights and Freedoms." Section IV.A concludes that were the issue to come before the Canadian Supreme Court, the Court would probably uphold Canada's protective measures as a reasonable means of preserving Canada's visage culturel.

In the American constitutional vernacular, Canada's protective regulations seek to advance an interest in the "dissemination of information from diverse and antagonistic sources." 12 Section IV.B determines, on the basis of current American constitutional doctrine, that the Canadian protective regulations would not be upheld were the issue decided by the U.S. Supreme Court.

While Canadian-style protective regulations would not pass constitutional muster in the United States, the U.S. Supreme Court has upheld a congressional statute with a similar (though less explicit) purpose in Turner Broadcasting System, Inc. v. FCC. ${ }^{13}$ In that case, cable providers challenged a statute requiring them to provide local broadcast stations to their subscribers, often in favorable channel positions. Those "must-carry" rules are analogous to Canada's protective cultural regulations in that both seek to protect works produced by a small community against a deluge of content from outside sources. Part V argues that the conception of popular culture as a valuable repository of local community perspectives most plausibly underlies Congress's motives in enacting the must-carry rules. Accordingly, the USTR should refine its international position on pop

10. The cabinet member responsible for developing policies regarding trade disputes with Canada is the U.S. Trade Representative. Office of the U.S. Trade Representative, USTR's Role, at http://www.ustr.gov/about-ustr/ustrrole.shtml (last visited Feb. 23, 2002). Part of the Executive Office of the President, the USTR is "the President's principal trade advisor, negotiator, and spokesperson on trade and related investment matters." Id.

11. The Canadian Charter of Rights and Freedoms is the Canadian analogue of the American Bill of Rights. Section 2(b) of the Charter guarantees freedom of expression. CAN. CONST. (Constitution Act, 1982) pt. I (Canadian Charter of Rights and Freedoms), \& 2 ("Everyone has the following fundamental freedoms:... freedom of thought, belief, opinion and expression, including freedom of the press and other media of communication ....").

12. Turner Broad. Sys., 512 U.S. at 663 (quoting Associated Press v. United States, 326 U.S. 1, 20 (1945)).

13. 512 U.S. 622. 
culture to match Congress's efforts to preserve a distinct visage culturel in America.

\section{Canadian Protective Measures for Television and Magazines}

No one denies the widespread presence of American pop culture in Canada. Despite its relatively small size, Canada remains the most important export market for U.S. pop culture. In 1989, sales of U.S. books to Canada represented $39.9 \%$ of all U.S. books sold abroad. ${ }^{14}$ Even more remarkable, $78 \%$ of all U.S. magazines sold abroad are sold in Canada. ${ }^{15}$ On the other hand, only $19 \%$ of the English-language magazines and $55 \%$ of the books Canadians read are of Canadian origin. ${ }^{16}$ Canada is also the largest per capita consumer and the second-largest absolute consumer of U.S. movies. ${ }^{17}$ Additionally, sales of U.S. television programs in Canada earn approximately US $\$ 125$ million per year. ${ }^{18}$ Contrarily, only $3-6 \%$ of the screen time in Canadian theaters ${ }^{19}$ and $39 \%$ of the television programming in $\mathrm{Canada}^{20}$ qualify as Canadian content.

Though nearly every country is penetrated by American mass media to some degree, Canada's situation is unique for several reasons. First, seventy percent of the Canadian population shares a primary language with Americans, thus facilitating Canadian absorption of U.S. cultural exports. ${ }^{21}$ Second, eighty percent of the Canadian population lives within sixty miles of the U.S. border, making American print publications easy to obtain. ${ }^{22}$ That proximity also enables Canadians to receive American television broadcast stations and Canadian cable companies to carry American cable stations. ${ }^{23}$

Canada's most protective cultural policies have always been its rules regarding U.S. periodicals. ${ }^{24}$ In 1929, the combined sales in Canada of four major American magazines were more than double the sales of the four

14. John Herd Thompson, Canada's Quest for Cultural Sovereignty: Protection, Promotion, and Popular Culture, in NAFTA IN TRANSITION 393, 399 (Stephen J. Randall \& Herman W. Konrad eds., 1995). Great Britain is in a distant second place, purchasing $8 \%$ of total U.S. book exports. Id. at 399 n. 21 .

15. Id. at 399. Again, Great Britain ranks second in this regard, purchasing $5 \%$ of all U.S. magazine exports. Id. at 399 n.21.

16. Cultural Indus. Sectoral ADVISORY Group ON INT'L TRADE, CANADIAN CUlture IN A GLODAL WORLD (1909), http://www.dfait maeci.gc.ca/tha nac/canculture e.asp.

17. Id.

18. Thompson, supra note 14 , at 399.

19. CULTURAL INDUS. SECTORAL ADVISORY GROUP ON INT'L TRADE, supra note 16.

20. Dep't of Can. Heritage, Introduction: Making Room for Canada's Voices, at http://www.pch.gc.ca/culture/report/HTM/2.htm (last visited Feb. 26, 2002).

21. Thompson, supra note 14, at 395.

22. Id.

23. See Amy E. Lehmann, Note, The Canadian Cultural Exemption Clause and the Fight To Maintain an Identity, 23 SYRACUSE J. INT'L L. \& COM. 187, 193-94 (1997).

24. Thompson, supra note 14, at 396. 
leading Canadian magazines. ${ }^{25}$ Seeking to prop up the floundering Canadian periodicals industry, publishing entrepreneurs and a "nationalist intelligentsia" that found U.S. mass culture to be a menace to Canadian values lobbied Parliament to enact a tariff on foreign publications. ${ }^{26}$ The Conservative government of the time responded by imposing Canada's first tariff on periodicals in $1931 .{ }^{27}$ Subsequently, sales of the five leading Canadian magazines rose by about sixty percent during the next four years, and U.S. magazine circulation in Canada fell by approximately the same amount. $^{28}$

In 1965, Tariff Code 9958 was enacted. ${ }^{29}$ It prohibited U.S. media companies from importing "special editions" of their periodicals to Canada. A "special edition" (also called a "split-run edition") is a version of a magazine-published originally in another country-with essentially the same substantive content as the original, but with more than five percent of its ads targeted to Canadians and not appearing in other versions of that issue. ${ }^{30}$ Publishers of split-runs recover their editorial costs through sales of ads in their home markets. This enables them to compete at an advantage with Canadian publishers whose profitability depends on attracting ad revenues in the Canadian market to cover editorial and production costs. ${ }^{31}$ The intended effect of Tariff Code 9958 was to prevent foreign publishers from selling special Canadian advertising editions of what were otherwise U.S. periodicals. ${ }^{32}$

In 1993, Time Warner sought to exploit a loophole in that import restriction. Instead of sending physical copies of a Canadian edition of Sports Illustrated across the border, it transmitted the editorial content electronically to Canadian printing facilities. ${ }^{33}$ Parliament reacted in 1995 with Bill C-103. That measure imposed a tax equal to eighty percent of all the advertising revenue of a split-run edition, regardless of that edition's

25. Mary Vipond, Canadian Nationalism and the Plight of Canadian Magazines in the 1920s, 58 CAN. HIST. REV. 43, 44 (1977).

26. Thompson, supra note 14, at 396.

27. Vipond, supra note 25 , at 59.

28. Id.

29. Canada-Certain Measures Concerning Periodicals, Report of the Panel, WTO Doc. WT/DS3 1/R (Mar. 14, 1997), reprinted in [1997] 1 WORLD TRADE ORG., DISPUTE SETTLEMENT REPORTS 481, 484 (2000), aff d in relevant part, Canada-Certain Measures Concerning Periodicals, Report of the Appellate Body, WTO Doc. WT/DS31/AB/R (July 30, 1997), reprinted in [1997] 1 WORLD TRADE ORG., DisPute SETTLEMENT REPORTS 449 (2000). Tariff Code 9958 was added to Schedule VII of the Customs Tariff. Schedule VII is executed through section 114 of the Customs Tariff. Customs Tariff, ch. 49, § 114, 1987 S.C. 1407, 1452, 3308-10.

30. Customs Tariff, ch. $49, \S 114,1987$ S.C. $1407,1452,3308-10$.

31. Robert Eberschlag, Culture Clash: Canadian Periodical Policies and the World Trade Organization, 26 MAN. L.J. 65, 68-69 (1998).

32. Id. at 69-70.

33. Hale E. Hedley, Canadian Cultural Policy and the NAFTA: Problems Facing the U.S. Copyright Industries, 28 GEO. WASH. J. INT'L L. \& ECON. 655, 674 (1995). 
physical origin ${ }^{34}$ Split-run magazines originating in Canada, however, were exempt from the tax ${ }^{35}$ The Canadian government argued that Bill C-103 was necessary to ensure the survival of fora for Canadian editorial and cultural content. ${ }^{36}$

The American govemment responded to Canada's discriminatory practices by invoking the WTO dispute settlement process. In that venue, the United States challenged not only Bill C-103, but also Tariff Code 9958. ${ }^{37}$ The WTO panel found that for the purposes of the General Agreement on Tariffs and Trade, magazines are consumer goods like any other commodity, and that both measures were inconsistent with Canada's trade obligations. ${ }^{38}$ Canada responded by introducing the Foreign Publishers Advertising Services Act. Also known as Bill C-55, the Act would have had approximately the same effect as Bill C-103, though technically it regulated advertising services rather than products. ${ }^{39}$ The Act was another explicit attempt to reserve a space for Canadian pop culture in defiance of what the WTO had ruled were Canada's international trade obligations. ${ }^{40}$ The United States, viewing Bill C-55 as a refusal to comply with the spirit of the WTO panel ruling, threatened to retaliate by imposing sanctions against Canadian steel, plastics, textiles, and lumber. ${ }^{41}$ After some negotiation, Canada agreed not to tax split-run periodicals in which Canadian advertisements constituted less than eighteen percent of the total ad content. Further, a split-run periodical could include a greater proportion of Canadian ads if it set up editorial facilities and staff in Canada and included at least fifty-one percent original content designated for the Canadian market. ${ }^{42}$ The current rules on split-run magazines in Canada are based on that compromise.

Different protective measures regulate Canadian television. The Canadian Broadcasting Act, which applies to broadcast, cable, and satellite

34. An Act To Amend the Excise Tax Act and the Income Tax Act, ch. 46, $\$ 36,1995$ S.C. at 5.

35. Peter Lichtenbaum \& Selma Lussenburg, Canadian Law, 31 INT'L LAw. 477, 477 (1997).

36. Id.

37. See Canada-Certain Measures Concerning Periodicals, Report of the Panel, supra note 29 , at 483 .

38. Id. at 587 .

39. Foreign Publishers Advertising Services Act, ch. 23, § 3, 1999 S.C. at 4.

40. When Bill C-55 was tableut in the I luvisc of Commons in October 1998, the Heritage Minister stated that the bill's aim was to channel advertising service dollars to Canadian publishers so that they could "produce original Canadian stories for and about Canadians." Can. Heritage, New Advertising Services Legislation Tabled (Oct. 8, 1998), at http://www.pch.gc.ca/ newsroom/news_e.cfm?Action=Display \&Code $=8$ NR098E. The Minister contended further that " [Canadians] must insist upon our own cultural space where we can express our ideas, our values and identity. This Act is consistent with Canada's longstanding cultural policies ...." Id

41. Valerie Lawton, Canada, U.S. End Trade Dispute: Compromise Gives Americans Share of Domestic Magazine Market, TORONTO STAR, May 26, 1999, at Al.

42. $I d$. Split-run periodicals that do not meet these requirements are subject to punitive fines. See Foreign Publishers Advertising Services Act, ch. 23, §§ 10-13, 1999 S.C. at 7-8. 
television distribution, emphasizes a need to protect Canadian cultural values. It declares that "the Canadian broadcasting system ... [is] essential to the maintenance and enhancement of national identity and cultural sovereignty" ${ }^{43}$ and that Canadian television should "safeguard, enrich and strengthen the cultural ... fabric of Canada." 44 Under the current regulations, private Canadian television broadcasters must air a minimum of sixty percent "Canadian content" programming in a given year. ${ }^{45}$ Further, those broadcasters must devote at least half of the period between 6:00 p.m. and midnight to Canadian content programming. ${ }^{46}$ The current rules for determining whether a program qualifies as Canadian content involve a point system. A program that has a Canadian producer and receives at least six of a possible ten points qualifies as Canadian content. The rules require that either the director or the screenwriter be Canadian (two points for each) and that either the highest-paid or the second-highestpaid actor be Canadian (one point for each). Additionally, at least seventyfive percent of the expenses incurred in producing the program must have been paid to Canadians. ${ }^{47}$

Of particular interest for the purposes of comparing Canadian television regulations with American ones are the provisions relating to cable providers. The Broadcasting Act specifies that cable providers "should give priority to the carriage of Canadian programming services and, in particular, to the carriage of local Canadian stations." ${ }^{48}$ Regulations promulgated by the Canadian Radio-Television and Telecommunications Commission pursuant to the Broadcasting Act instruct cable providers to "ensure that a majority of the video channels ... received by a subscriber are devoted to the distribution of Canadian programming services." 49

\section{The Collision of Canadian and American PeRsPeCtives ON FREE SPEECH AND POP CULTURE}

Studies show that Canadians overwhelmingly support their government's attempts to protect their cultural industries and that they want to see more of their culture reflected in the mass media they consume. ${ }^{50} \mathrm{~A}$

43. Broadcasting Act, ch. $11, \S 3(1)(b), 1991$ S.C. $117,119$.

44. Id. \& 3(1)(d)(i), 1991 S.C. at 119.

45. Television Broadcasting Regulations, SOR/87-49. § 4(6), 121 C. Gaz. pt. I, at 336, 339 (Jan. 21, 1987).

46. Id. $\S \S 4(2), 4(7)$ (b), 121 C. Gaz. pt. II, at 338-39.

47. Can. Heritage, Canadian Content Rules, at http://www.pch.gc.ca/culture/cancon/can_con.html (last modified Mar. 8, 2001).

48. Broadcasting Act, ch. $11, \S 3(1)(\mathrm{t})(\mathrm{i}), 1991$ S.C. $117,123$.

49. Broadcasting Distribution Regulations, SOR/97-555, § 6(2), 131 C. Gaz. pt. I, at 3541, 3550 (Dec, 12, 1997).

50. Martin C. Glass \& David M. Rhodes, Catching the Wave: Should Canada Follow the Global Trend Toward Spectrum Auctions?, 44 MCGILL L.J. 141, 160 (1999). 
1995 survey reported that $72 \%$ of Canadians thought that strengthening Canadian culture could facilitate national reconciliation between Quebec and Anglophone Canada. Most believed that protecting Canadian culture from U.S. influences and preserving a sense of cultural distinctiveness from the United States were the most important ways the government could strengthen Canadian culture. ${ }^{51}$ More concretely, another survey indicated that $78 \%$ of Canadians supported content-based protectionist measures and that $84 \%$ (93\% in Quebec) believed the federal government should protect Canada's cultural industries in trade negotiations. ${ }^{52}$

Canadians strongly support their government's protective cultural measures for several reasons. First, there is a sense that Canadian cultural works, by reflecting Canadian mores, experiences, and perspectives, animate the contours of Canadian society. An advisory group to the Minister of Foreign Affairs and International Trade stated:

Our culture-our ideas, songs and stories-gives meaning to who we are as Canadians. Through cultural products ... we express ideas and perspectives, and we share stories and images that are uniquely Canadian .... [Cultural products] help shape our sense of identity. They add richness to our lives.

In Canadian books, magazines, songs, films and radio and television programs, we are able to see and understand ourselves. We develop a more cohesive society and a sense of pride in who we are as a people and a nation. ${ }^{53}$

One commentator argues that Canadian cultural works enable Canadians to make more informed public choices. ${ }^{54}$ Canadian cultural products, having originated in a Canadian community, are a source of information about that community. ${ }^{55}$ Further, Canadian cultural works provide a "meeting place" for Canadians to interact with each other and learn about salient perspectives and experiences that surround them. "What

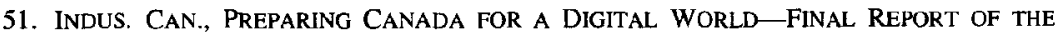
INFORMATION HIGHWAY ADVISORY COUNCIL ch. 5 (1997), http://strategis.ic.gc.ca/SSG/ ih01643e.html.

52. Id.

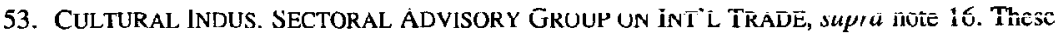
comments track the official position of the Department of Heritage. See Dep't of Can. Heritage, supra note 20 ("Canadian culture helps us to understand and to celebrate our lives as Canadians. [It] is the shared experience of being Canadian.").

54. Daniel Schwanen, A MatTer of Choice: Toward a More Creative Canadian POlICY ON CULTURE 9 (C.D. Howe Inst., Commentary No. 91, 1997).

55. The Report of the Royal Commission on National Development in the Arts, Letters and Sciences lauded Canadian newspapers and periodicals in 1951 as "probably the chief source of knowledge to Canadians of their country and of one another." ROYAL COMM'N ON NAT'L DEV. IN THE ARTS, LETTERS \& SCIS., REPORT ch. V, para. I (1951), http:/www.nlc-bnc.ca/massey/h5400-e.html. 
is important," the commentator says, "is the ability to access products and services that transmit the cultural and informational signals individuals need to ensure their informed participation in the community." 56 According to this view, Canadian cultural products can "make democratic government possible and better government probable." 57

Canadians also support their government's protective measures because they view pop culture as crucial to maintaining Canadian sovereignty. Many contend that Canada's strength as a nation depends on its ability to distinguish itself from the United States and that Canadian pop culture is vital to that objective. ${ }^{58}$ Thus, they argue that "the presence or absence of culture ... has a direct bearing on the security of the state." ${ }^{59}$ As early as 1929, the Royal Commission on Radio Broadcasting was concerned that the inundation of American ideas through the new medium of radio would " 'mould the minds of the young people ... to ideals and opinions that are not Canadian." ${ }^{60}$ In 1957, the Royal Commission on Broadcasting found that while Canadians could have cheaper radio and television if Canadian stations became outlets of American networks, it would not be possible " to have a Canadian nation at all" if that occurred. ${ }^{61}$ Franklyn Griffiths, a professor of political science at the University of Toronto, argued recently that for Canada, "defense of sovereignty comes down to our ability to nourish the processes that hold us together as a people with purposes and a destiny of our own .... Defense of sovereignty is, au fond, a matter of culture." ${ }^{2}$ Culture, he said, is "utterly fundamental in securing [Canada] against internal as well as external threats to its well-being and cohesion." ${ }^{63}$

That Canadians value their cultural works because those works promote community-building, dialogue, and Canadian sovereignty does not fully explain why they support their government's protective measures. There is significant evidence that were Canadian cultural industries not protected from cheaper foreign imports, their economic survival would be severely

56. SCHWANEN, supra note 54 , at 9.

57. TASk Force on the Can. Magazine Indus., A Question of Balance 1 (1994) (quoting the report of the O'Leary Royal Commission on Publications).

58. See Roger Frank Swanson, Canadian Cultural Nationalism and the U.S. Public Interest, in Canadian Cultural Nationalism 55, 56 (Janice L. Murray ed., 1977) (arguing that "Canadian cultural nationalism is grounded in a century-long quest for a national identity that defines a Canadian 'separateness' from the United States").

59. Kevin Dowler, The Cultural Industries Policy Apparatus, in THE CULTURAL INDUSTRIES N CANADA 328, 337-38 (Michael Dorland ed., 1996).

60. ISAIAH LitVAK \& Christopher MaUle, Cultural SOVEREIGNTY 8 (1974) (quoting the report of the Royal Commission on Radio Broadcasting).

61. Id. at 9 (quoting the report of the Royal Commission on Broadcasting).

62. GRIFFITHS, supra note 6, at 7.

63. Id. at 9. An advisory group to the Minister of Foreign Affairs and International Trade has made similar claims, arguing that "[a]s countries become more cconomically integrated, nations need strong domestic cultures and cultural expression to maintain their sovereignty and sense of identity." Cultural Indus. SECTORAL AdViSORY Group ON INT'L TRADE, supra note 16. 
threatened. ${ }^{64}$ For example, American publishers of "split-run" magazines ${ }^{65}$ enjoy significant economic advantages over Canadian publishers, with potentially devastating results. Having recovered the costs of their magazine's substantive content through advertising in the much larger American market, American publishers can sell advertising in Canada at lower rates than their Canadian competitors. ${ }^{66}$ Since Canadian periodicals are unable to penetrate the American market to recoup production costs in a similar way, ${ }^{67}$ they are at a significant competitive disadvantage. The Task Force on the Canadian Magazine Industry concluded that the effects of the unregulated sale of American split-run magazines in Canada would be "a downward spiral." 68 Competition from split-runs would reduce the operating profits of Canadian magazines by up to eighty-five percent. This would cause ninety-four percent of the currently profitable Canadian magazines to realize a zero operating profit. Moreover, those magazines that attempted to stay in business would be forced to reduce their editorial budget, thus reducing the quality of their content. As the number of editorial pages decreased, circulation and profits would further decline due to reduced editorial quality. ${ }^{69}$

Even setting aside split-run periodicals, those who import other forms of pop culture media from much larger markets have a distinct advantage over Canadian cultural purveyors. Creating and marketing products for the Canadian market alone is costly because Canada's relatively small size affords few opportunities for realizing the cost efficiencies enjoyed by creators of content in larger markets. ${ }^{70}$ For example, one hour of prime-time television created for the Canadian market can cost about $\$ 1$ million, while it costs only one-tenth of that amount to purchase an hour of American drama. ${ }^{71}$ Citing these economic factors, Canadian commentators and the Canadian government argue that the viability of Canadian cultural

64. This was one of the arguments Canada advanced before the World Trade Organization. Canada-Certain Measures Concerning Periodicals, Report of the Panel, supra note 29, at 493.

65. See supra text accompanying notes 30-31, 42.

66. Eberschlag, supra note 31 , at 68 .

67. See ROYAL COMM'N ON NAT'L DEV. IN THE ARTS, LETTERS \& SCIS., supra note 55, ch. II, para. 24 ("The Canadian periodical cannot... invade the American market [because] Americans ... simply do not know enough about Canada to appreciate Canadian material.").

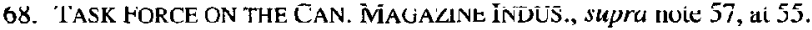

69. Id. at 54-55.

70. See Gov't of CaN., Vital Links: CanAdian Cultural Industries 11 (1987); CUltural INdus. SECTORAL ADVISORY Group ON INT'L TRADE, supra note 16. Because Canadian cultural products are not very popular in those larger foreign markets, Canadian content creators are unable to realize those economies of scale. See, e.g., Liss Jeffrey, The Impact of Technological Change on Canada's Affirmative Policy Model in the Cultural Industry and New Media Sectors, 25 CAN.-U.S. L.J. 379, 384 (1999) (noting the difficulties of a Canadian television station in penetrating the American market).

71. Cultural Indus. Sectoral AdVisory Group ON INT'L TRADE, supra note 16. The figure is in Canadian dollars. 
industries would be jeopardized by an unregulated influx of foreign cultural products. ${ }^{72}$

Therefore, the special value Canadians attribute to pop culture works, coupled with the potentially crippling economic threat Canadian cultural industries face from foreign competition, leads Canadians to support their government's protective cultural policies. ${ }^{73}$ Those policies aim to treat pop culture differently in the realm of international trade. In contrast, the overwhelming sentiment in the United States-and the position the United States adopts in trade disputes with Canada-is that pop culture products are merely ordinary commodities. Those sentiments are reflected in former FCC Chairman Mark Fowler's remark that a television is nothing more than "a toaster with pictures." 74

Arguably, the U.S. position is rooted in fundamental and "widelyshared ... beliefs in the intrinsic goodness of free markets, free trade, and free speech" that "transcend[] ... political divides." 75 Further, the comparative distrust Americans feel toward government makes them especially wary of measures that aim to restrict what individuals may consume. The view is that an exclusionary prohibition, however dressed up, is at least partially premised on the antidemocratic idea that individuals, left to their own devices with a real choice, cannot be trusted to make the "right" choice in the popular culture they consume. Additionally, few Americans would seriously consider imported works to be a threat to American sovereignty, due to the dominant position of the United States on the global stage and the saturation of American life with American pop culture products.

Furthermore, U.S. free speech doctrine holds that content-based restrictions on speech are inherently suspect because of the strong possibility that such measures aim to suppress particular views. ${ }^{76}$ As such, any content-based rule must advance a compelling interest to withstand First Amendment scrutiny. According to current U.S. constitutional doctrine, the interest in promoting a diversity of ideas in the public sphere is not compelling enough to justify a content-based restriction on speech. ${ }^{77}$ Adopting this "first amendment optic," American trade officials view the

72. See, e.g., id.; Jeffrey, supra note 70 , at 382.

73. Of course, some Canadians criticize their government's protective rules. Most adopt the American complaint that these cultural protections are nothing more than venal economic protectionism. One critic remarked: "Show me a cultural protectionist, and I'll show you somebody with a subsidy he wants to keep. Culture is simply the garbage can lid these types use to shield themselves from their critics." Michael Harris, Editorial, Grit Strategy Is Pulp Fiction, TORONTO SUN, Jan. 21, 1997, at 17.

74. Nossiter, supra note 2, at 402 (quoting Mark Fowler).

75. Goodenough, supra note 5, at 205.

76. See Simon \& Schuster, Inc. v. Members of the N.Y. State Crime Victims Bd., 502 U.S. 105, 116 (1991); infra Section IV.B.

77. See infra text accompanying notes 130-137. 
explicit objective of privileging Canadian over foreign content as antithetical to the fundamental First Amendment principle guaranteeing the free flow of information. ${ }^{78}$ All of these factors have provoked Americans to cast Canadian cultural nationalism as merely a "non-tariff barrier to the free flow of goods" or as "blatant anti-Americanism." 79

\section{COMPARING FREEDOM OF SPEECH DOCTRINES ON POP CULTURE DISCRIMINATION}

This Part examines the constitutionality of the Canadian protective rules from Canadian and American perspectives. Perhaps not surprisingly, the free speech doctrine in each country is consistent with the longstanding Canadian and American positions on this matter. Though the issue has never been litigated in Canada, the free expression doctrine in that country suggests that Canadian courts would uphold the protective rules. The Canadian Supreme Court has stated that the interest in preserving a distinct French culture in Quebec-Quebec's "visage linguistique" ${ }^{80}$-is compelling enough to justify a law requiring French to be the predominant language on outdoor signs in that province. ${ }^{81}$ Similarly, since Canadians consume predominantly foreign pop culture products despite their government's protective measures, the Canadian Supreme Court would likely hold that the interest in preserving a space for distinctly Canadian cultural exchange would justify those rules. Conversely, the U.S. Supreme Court would almost certainly find those same rules unconstitutional, because it has held that the interest in promoting a diversity of views in the public sphere is not compelling enough to justify content-based regulations. ${ }^{82}$ That interest in a "widespread dissemination of information from a multiplicity of sources" may justify only a content-neutral rule. ${ }^{83}$

\section{A. The Canadian Doctrine}

Canadian magazine and broadcast rules are content-based. They privilege Canadian works over those from other nations to achieve greater dissemination of purportedly distinct Canadian viewpoints and ideas. One might argue that the rules appear to discriminate only on the basis of the geographic souice of a particular work and not necessarily on the basis of its content. In support of that proposition, one could point out that a

78. Swanson, supra note 58 , at 56 .

79. Id.

80. See infra notes $109-110$.

81. Ford v. Quebec, $[1988] 2$ S.C.R. $712,780$.

82. See infra text accompanying notes 130-137.

83. Tumer Broad. Sys., Inc. v. FCC, 512 U.S. 622, 662-63 (1994). 
Canadian program or magazine designed to emulate American culture for an American audience would be deemed "Canadian content" while an American work intended to adopt a Canadian outlook would not qualify. There are several reasons, however, why the rules should be construed as overwhelmingly privileging works on the basis of content. First, as a practical matter, American products adopting a Canadian outlook and targeting Canadian audiences are rare. The vast majority of the pop culture works imported from the United States are also sold to Americans, and because the United States is a larger market, those works are naturally geared to Americans. In fact, the major American media companies that sell their products in Canada wish to do so precisely because only minimal substantive changes, if any at all, are necessary to sell those Americangeared products to Canadians. ${ }^{84}$ Using a geographic restriction as a proxy for a restriction on non-Canadian content is thus fairly accurate. Second, an explicit goal of the protective rules is to promote Canadian conversations and Canadian cultural exchange. ${ }^{85}$ The rules regard Canadians as different from Americans in ways that are borne out in the cultural works that Canadians produce. Thus, when viewed through the lens of Canada's constant struggle to differentiate itself from the United States, these rules intend to privilege the purported distinct ideas, perspectives, and experiences of Canadians.

Given that Canada's rules have both the purpose and the effect of restricting expression on the basis of content, it may appear surprising that these rules have never been challenged on that basis in Canada. While there have been several disputes in which such a challenge could have been raised, the litigants in each case failed to raise the question properly. ${ }^{86}$ That these regulations have never been challenged on freedom of expression grounds, despite their explicit aim to restrict speech in a content-based manner, is consistent with Canadian views of the importance of indigenous pop culture.$^{87} \mathrm{I}$ argue below that were the question to come before it, the Canadian Supreme Court would likely hold that the protective, contentbased measures pass constitutional muster.

84. When asked why his magazine was fighting to preserve its Canadian operation, a former Time magazine editor replied: "They don't call Canada the candy store for nothing." Time Canada Turns More Canadian, BUS. WK., Oct. 20, 1975, at 52, 52.

85. See supra Part III.

86. See, e.g., Express Vu Inc. v. NII Norstat Int'l Inc., [1998] 1 F.C. 245, 269-70 (declining to consider whether an absolute prohibition against receiving certain radio communications was a breach of Section 2 (b) because the issue was not properly raised by the parties); R. v. Knibb, [1997] 8 W.W.R. 115, 129 (Alta. Prov. Ct.) (same). No litigant has ever challenged on freedom of expression grounds Canada's most restrictive periodicals policies. Those policies are described supra text accompanying notes 24-42.

87. I describe those views supra Part III. 
A Canadian court evaluates a measure alleged to infringe the Charter's guarantee of freedom of expression (Section $2(b))^{88}$ in two stages. First, the court assesses whether the rule has the purpose or effect of limiting the right to freedom of expression. If it determines that the law has that purpose or effect, the court must determine next whether the law may be justified under Section 1 of the Charter. Section 1 asks whether a provision that limits a Charter right "can be demonstrably justified in a free and democratic society." ${ }^{89}$ If the court finds that the provision is proper despite its limitations on speech, the provision will stand..$^{90} I$ argue below that Canada's protectionist measures would be held to infringe Section 2(b), but would be justified by Section 1 .

According to the Canadian Supreme Court, protecting freedom of expression is " 'fundamental' because in a free, pluralistic and democratic society we prize a diversity of ideas and opinions for their inherent value both to the community and to the individual." 91 This explicit recognition of the value of a diversity of ideas, and the Court's general view that the Charter should be interpreted broadly, has caused it to hold that any activity that conveys or attempts to convey a meaning falls within the scope of Section 2(b).$^{92}$ As a result, a Canadian court adjudicating a freedom of expression case will almost always conclude that the impugned law infringes Section 2(b). ${ }^{93}$ This nearly all-encompassing view of expression is the basis of the Canadian principle of "content-neutrality." ${ }^{94}$ The Supreme Court has stated that although "not all expression is equally worthy of protection," 95 all expression-regardless of its content-is nevertheless protected under Section 2(b).$^{96}$ The Court has held that considerations of the worthiness of content are appropriate in the Section 1 analysis, but not to a determination of whether such content is expression. Further, and unlike the American jurisprudence in this area, the Court has found that the category of commercial speech "do[es] not have any particular meaning or

88. Section 2(b) of the Charter reads: "Everyone has the following fundamental freedoms: ... freedom of thought, belief, opinion and expression, including frecdom of the press and other media of communication ...." CAN. CONST. (Constitution Act, 1982) pt. 1 (Canadian Charter of Rights and Freedoms), $\$ 2(b)$.

89. Id. $\$ 1$.

90. 2 Peter W. hogg, Constitutional Law ur Canaũa chi 40.2, ai 40-6 (4th cd. 1997).

91. Irwin Toy Ltd. v. Quebec, [1989] 1 S.C.R. 927, 968; see also Retail, Wholesale \& Dep't Store Union v. Dolphin Delivery Lid., [1986] 2 S.C.R. 573, 583 (stating that "discussion of varying ideas" is necessary to Canadian democracy).

92. R. v. Keegstra, [1990] 3 S.C.R. 697, 826; Irwin Toy, [1989] 1 S.C.R. at 969; 2 HOGG, supra note 90 , ch. $40.5(\mathrm{a})$, at $40-10$.

93. 2 HOGG, supra note 90 , ch. 40.2 , at $40-6$.

94. Recall that my use of "content-neutral" and "content-based" elsewhere refers to the American meanings of these terms and not to the Canadian ones. See supra note 8.

95. Rocket v. Royal Coll. of Dental Surgeons, [1990] 2 S.C.R. 232, 247.

96. Keegstra, [1990] 3 S.C.R. at 759-60. 
significance in Canadian constitutional law." 97 That some activity has a commercial purpose does not "remove[] the expression contained therein from the scope of protected freedom." 98

In summary, only activities that are "purely physical and do[] not convey or attempt to convey meaning" expression under the Supreme Court's expansive reading of the Charter. Thus, there is no doubt that the materials subject to the Canadian content regulations-magazines, television, films, music, and any advertising they may contain-are expression protected by Section 2(b).

A court will hold that a law or regulation violates Section 2(b) if it has a purpose or effect of restricting expression. ${ }^{100}$ Since the Canadian content rules have both the purpose and the effect of reducing the extent of the dissemination of non-Canadian pop culture works, and since those works are undoubtedly expression protected by the Charter, the Court would hold that these rules violate Section 2(b).

Whether the Canadian Supreme Court would rule that the Canadian protective measures infringe the Charter would thus turn on a Section 1 analysis. Although there is no direct precedent in this area, I argue below that the Supreme Court's reasoning in Ford v. Quebec ${ }^{101}$ indicates that these provisions would likely be upheld.

In Ford, the Supreme Court considered whether section 58 of the Quebec Charter of the French Language-which required that outdoor signs, posters, and commercial advertising be in French only-infringed the Charter's freedom of expression guarantee. ${ }^{102}$ The threshold question was whether Section 2(b) includes the freedom to express oneself in the language of one's choice. After all, the law did not directly restrict the ideas expressed on the signs; its requirements applied only to the language used. The Court held that language " "is not merely a carrier of content.... Language itself is content." ${ }^{103}$ It stated that "[1]anguage is so intimately related to the form and content of expression that there cannot be true freedom of expression ... if one is prohibited from using the language of one's choice." ${ }^{104}$ Thus, the Court held that the Quebec sign law was as much a content-based restriction as a law that restricted expression on the basis of the viewpoints or ideas expressed. Applying the Canadian content-

97. Ford v. Quebec, [1988] 2 S.C.R. 712, 755.

98. Id. at 766 .

99. Irwin Toy Ltd. v. Quebec, [1989] 1 S.C.R. 927, 969.

100. R. v. Big M Drug Mar Ltd., [1985] I S.C.R. 295, 331-32.

101. [1988] 2 S.C.R. 712.

102. Id. at 721 .

103. Id. at 750 (quoting Joshua A. Fishman, The Sociology OF LANGUAGE 4 (1972)).

104. Id. at 748 . 
neutrality principle, the Court held that the sign law infringed Section 2(b). ${ }^{105}$

The Court considered next whether the Quebec language restriction was nonetheless "demonstrably justified in a free and democratic society" under Section $1 .{ }^{106}$ When Canadian courts make that inquiry, they apply the test elaborated in $R . v$. Oakes ${ }^{107}$ The two-prong Oakes test requires a court to determine whether the legislation bears on a "pressing and substantial concern" and whether "the means chosen to attain [the government's] objectives ... [are] proportional or appropriate to the ends." ${ }^{108}$ The Quebec Attorney General argued that the objective of the French-only policy was to ensure that the Quebec visage linguistique ${ }^{109}$ reflected the predominance of French in the province. Without rules prohibiting English on exterior signs, the Attorney General argued, Quebec's visage linguistique would give the impression that English was as significant as French in the province. Due to the asserted vulnerable position of the French language in Quebec and Canada, such a false visage linguistique would reinforce the concern among Francophones that "the French language was threatened and... would ultimately disappear." 110 This concern, the Attorney General argued, would become a self-fulfilling prophecy. Young Francophones would infer that the language of success and advancement was English, and Quebec Anglophones would feel no great need to learn French. The Court held that Quebec's interest in preserving the French visage linguistique-and thus the viability of the French language in Quebec-was "a response to a substantial and pressing need" 111 and therefore satisfied the first prong of the Oakes test.

The Court was not convinced, however, that the sign law satisfied the second "proportionality" prong of the Oakes test. It held that the objective of protecting the viability of French did not require that outdoor signs be only in French. ${ }^{112}$ The Court suggested that "whereas requiring the predominant display of the French language, even its marked predominance, would be proportional to the goal of promoting and

105. See id. at 766-67. $\$ 1$.

106. CAN. CONST. (Constitution Act, 1982) pt. I (Canadian Charter of Rights and Freedoms),

107. [1986] 1 S.C.R. 103, 138-39.

108. R. $\checkmark$ Edwards Bocks \& Art Ltd., [1086] 2 S.C.R. 713, 768. Readers familiar with the U.S. Supreme Court's levels of scrutiny will recognize the similarities here. For example, strict scrutiny requires that a content-based limit on expression be "necessary to serve a compelling state interest and . . . namowly drawn to achieve that end." Widmar v. Vincent, 454 U.S. 263, 270 (1981).

109. This French phrase might be best understood as referring to the visual cues-like billboards and stop signs-that would cause a person visiting Quebec to draw inferences about the dominant language of the population.

110. Ford, [1988] 2 S.C.R. at 778.

111. Id. at 777 .

112. Id. at $779-80$. 
maintaining a French 'visage linguistique' in Quebec..., requiring the exclusive use of French has not been so justified." 113 Therefore, the Court overturned the Quebec sign law not because the objective was not "pressing and substantial" - the Court found that protecting French language and culture was a pressing and substantial concern-but because requiring that French be the exclusive language on outdoor signs went too far. The Court indicated further that the law would have been upheld had the legislature merely required that French be the "marked[ly] predominan [t]" language used. ${ }^{114}$

The similarities between the Quebec sign laws and the Canadian content regulations are instructive. In both situations, governments enacted restrictions on expression based on content. In Ford, the Court ruled that Quebec's language restrictions were effectively restrictions on the basis of content. Similarly, Canada's cultural regulations imposing burdens on nonCanadian works are also content-based since they have the purpose and effect of privileging "Canadian" ideas and perspectives over foreign ones. Further, in Ford, the Quebec government had banned shopkeepers from using languages other than French on outdoor signs to ensure that Quebec's visage linguistique reflected the actual linguistic predominance of French in Quebec. The Quebec government argued that a deterioration of Quebec's visage linguistique would dramatically reduce the actual prevalence of French in Quebec. Similarly, the federal government's Canadian content rules aim to preserve Canada's visage culturel. Without limitations on foreign (especially American) pop culture imports, the government argues, the overwhelming presence of foreign material will "stifle ... [Canadian] creative effort[s]" 115 and contribute significantly to the ultimate demise of Canadian culture.

In Ford, the Supreme Court found that the Quebec government's objective of preserving the French visage linguistique was "pressing and substantial" because of the subordinate position of the French language in Canada relative to English. To buttress that assertion, the Court referenced studies asserting that the threatened position of French in Canada was due in substantial part to the relative populations of Francophones and Anglophones in Canada. ${ }^{116}$ That Francophones constituted a minority meant that there was a real danger that the French language, if not protected,

113. Id. at 780.

114. Id.

115. ROYAL COMM'N ON NAT'L DEV. IN THE ARTS, LETTERS \& SCIS., supra note 55, ch. II, para. 26.

116. According to the studies, the major factors responsible for the threatened position of the French language in Canada were "(a) ... a decline in the Quebec francophone proportion of the Canadian population as a whole; (b) the decline of the francophone population outside Quebec as a result of assimilation; [and] (c) the greater rate of assimilation of immigrants to Quebec by the anglophone community of Quebec." Ford, [1988] 2 S.C.R. at 778. 
would disappear in Canada. Similarly, one could argue that the large disparity between the populations of Canada and the United States (the United States has over nine times as many people as Canada does ${ }^{117}$ ) means that a real threat to Canadian culture exists. The difference in size of the Canadian and U.S. economies also supports the proposition that Canadian cultural industries may not withstand an unfettered inundation of American cultural products. This would be especially true in the split-run magazine industry, where U.S. publishers are able to make up their substantive editorial costs through U.S. sales and can offer advertising in Canadian editions at a discount relative to Canadian publications. ${ }^{18}$ This perceived threat to Canadian culture is manifested in a Department of Heritage publication stating that "Canada's insistence on its own cultural space and on the importance of cultural diversity has much to do with living next door to the most powerful economic and cultural dynamo in the world." 119 Thus, given that the Court found the threat to Quebec's visage linguistique to be compelling, it would likely find the threat to Canada's visage culturel to be equally so.

The Supreme Court held in Ford that the French language law did not satisfy the proportionality prong of the Oakes test. The Court held that the absolute ban on non-French languages was excessive because a less restrictive law that required a "marked predominance" of French would have successfully realized Quebec's goal. None of the Canadian content regulations imposes an absolute ban on dissemination of or access to nonCanadian works of popular culture. In fact, despite Canada's protectionist cultural policies, it is foreign pop culture works that are predominant in Canada. Even with the current restrictions in place, $81 \%$ of the Englishlanguage consumer magazines sold in Canada-generating $63 \%$ of that country's total circulation revenue-are foreign. ${ }^{120}$ Further, $79 \%$ of retail sales of tapes, CDs, and concerts, and $85 \%$ of film distribution revenues, are generated by foreign works. ${ }^{121}$ Non-Canadian films also account for between $94 \%$ and $97 \%$ of the screen time in Canadian theaters, ${ }^{122}$ and $61 \%$ of all television programming in Canada is of foreign origin. ${ }^{123}$ The only

117. The population of Canada as of July 2001 was about 31 million. Statistics Can., Canadian Statistics-Population, Canada, the Provinces and Territories, at http://www.statcan.ca/ english/Pgdb/People/Population/demo02.htm (last modified Feb. 22, 2002). The extimated population of the United States at that time was roughly 285 million. Population Div., U.S. Census Bureau, Time Series of National Population Estimates: April 1, 2000 to July 1, 2001, at http://eire.census.gov/popest/data/national/populartables/table0l.php (last modified Dec. 27, 2001).

118. See supra text accompanying notes 65-69.

119. Dep't of Can. Heritage, supra note 20.

120. Cultural Indus. SECTORAL AdVisory Group ON INT'L TRADE, supra note 16.

121. Id.

122. Id.

123. Dep't of Can. Heritage, supra note 20. 
area where Canadian cultural products are predominant (if by "predominant" one means that they account for more than fifty percent of total consumption) is books; $55 \%$ of book sales in Canada are of a Canadian origin. ${ }^{124}$ Thus, Canada's protective cultural measures are not the type of outright ban that the Court found to be disproportionate in Ford. ${ }^{125}$ Given that a rule requiring the "marked predominance" of French would have passed constitutional muster in Ford, the Canadian content rules, which maintain the "marked predominance" of foreign cultural products in the Canadian market, would likely be upheld.

\section{B. The American Doctrine}

Though there is a lively academic debate in the United States about whether promoting a diversity of ideas in the public domain is an acceptable rationale for content-based restrictions on expression, ${ }^{126}$ the First Amendment doctrine has followed Justice Holmes's "marketplace of ideas" theory. ${ }^{127}$ That theory holds that viewpoints exist in the public domain in much the same way as ordinary goods exist in the market. And, just like in the market for commodities, the ideas that the majority believes to be persuasive or true will flourish, and ideas that are thought to be unpersuasive or foolish will be relegated to obscurity. This theory of free speech holds that it should be the majority - and not the state-that decides whether a viewpoint survives in the public domain. The way to counter ideas one does not like is not to prohibit those ideas from being expressed, but to rebut those unlikable ideas with more persuasive ones. In this way, the view that the majority finds most persuasive will prevail. ${ }^{128}$ The upshot of the "marketplace of ideas" theory is that the state may, within some constraints, subsidize speech to promote a particular idea or form of communication. ${ }^{129}$ The state may not, however, enact measures that restrict

124. CULTURAL INDUS. SECTORAL ADVISORY GROUP ON INT'L TRADE, supra note 16.

125. One of the objectives of the Canadian government's cultural policies is "to ensure that Canadian cultural content is available to all Canadians-without limiting their access to foreign cultural products." Id.

126. See, e.g., LEE C. Bollinger, IMAGEs of A FreE Press 133-45 (1991); Ronald W. Adelman, The First Amendment and the Metaphor of Free Trade, 38 ARIZ. L. REV. 1125 (1996); Owen M. Fiss, Why the State?, 100 HARV. L. REv. 781 (1987); Kathleen M. Sullivan, Free Speech and Unfree Markets, 42 UCLA L. REV. 949 (1995); Cass R. Sunstein, The First Amendment in Cyberspace, 104 YALE L.J. 1757, 1759-65 (1995).

127. Justice Holmes was the first Supreme Court Justice to use the metaphor "free trade in ideas" in his dissent in Abrams v. United States, 250 U.S. 616, 630 (1919) (Holmes, J., dissenting).

128. Holmes's theory does not claim to predict that the "moral" or "tnue" views will prevail over "immoral" or "false" ones. Instead, the pervasiveness of an idea will be linked to the number of people who find it to be persuasive. In this way, his theory avoids the potentially cornupting governmental responsibility for making determinations of morality or truth.

129. Goodenough, supra note 5, at 234. 
speech on the basis of content or viewpoint without a compelling justification. The current constitutional doctrine in the United States holds that the interest in increasing the diversity of the ideas in the public domain, while important enough to justify a content-neutral regulation of speech, is not sufficiently weighty to justify a regulation on the basis of content.

The Court's distaste for content-based measures that aim to promote a greater diversity of ideas is evident in Miami Herald $v$. Tornillo ${ }^{130}$ In that case, the Court invalidated a "right-of-reply" statute that applied to newspapers. If a newspaper published an article criticizing a political candidate, the statute required that the newspaper provide him or her with space in the newspaper-free of charge-to respond. ${ }^{131}$ The asserted purpose of the statute was to solve a market failure in the marketplace of ideas. The government argued that economic factors had caused a large number of metropolitan newspapers to disappear and "made entry into the marketplace of ideas served by the print media almost impossible." 132 This resulted in a press "that [had] become noncompetitive and enormously powerful and influential in its capacity to manipulate popular opinion and change the course of events." ${ }^{133}$ Thus, "[t]he First Amendment interest of the public in being informed [was] said to be in peril because the 'marketplace of ideas' [was] a monopoly controlled by the owners of the market." 134 The statute, by requiring that newspapers present several perspectives on some issues, was aimed at enhancing free speech and promoting the " broad societal interest in the free flow of information to the public."' 135

The Supreme Court held that the interest in ensuring that diverse viewpoints were more widely available could not justify a content-based restriction on speech in the press. The Court stated that "any such a compulsion to publish that which 'reason' tells [an editor] should not be published is unconstitutional." ${ }^{136}$ Further, a rule requiring that a particular article be published is a limit on expression in the same way as a rule forbidding publication of specified matter, because it "exacts a penalty on the basis of the content of a newspaper ... in terms of the cost in printing

130. Mrami Heraid Fubi'g Co. v. Tomilio, 4 is U.J. 241 ( $i 974$ ).

131. Id. at 244.

132. Id. at 251 .

133. Id. at 249 .

134. Id. at 251 .

135. Id. at 245 (quoting Tornillo v. Miami Herald Publ'g Co., 287 So. 2d 78, 82 (Fla. 1973) (upholding the statute)).

136. Tornillo, 418 U.S. at 256 (internal quotation marks omitted). The concurrence stated that "the First Amendment erects a virtually insurmountable barrier between government and the print media so far as government tampering, in advance of publication, with news and editorial content is concerned." Id. at 259 (White, J., concurring). 
and composing time and materials and in taking up space that could be devoted to other material the newspaper would have preferred to print." 137

In Minneapolis Star \& Tribune v. Minnesota Commissioner of Revenue, the Court invalidated a tax on printing materials that applied only to certain newspapers. ${ }^{138}$ A tax that applies only to the press, the Court stated, suggests the "presumptively unconstitutional" goal of suppressing expression. ${ }^{139}$ That the tax applied only to certain members of the press "presents such a potential for abuse that no interest suggested by [the state] can justify the scheme." 140

In light of Tornillo and Minneapolis Star, Canadian-style protective magazine regulations would almost certainly be held unconstitutional. Under the current protective scheme, magazines that contain less than fiftyone percent original Canadian content and whose advertisements directed to the Canadian market exceed eighteen percent of their total ad content are subject to large punitive fines. ${ }^{141}$ Since those penalties apply only to certain magazines based on their content, no interest asserted by the government could justify them under Minneapolis Star. Moreover, the fines have the explicit purpose and likely effect of preventing magazines with particular content from being published in Canada. Since no "'government agency ... can tell a newspaper in advance what it can print and what it cannot," ${ }^{142}$ those taxes would violate the Tornillo holding.

While the differences between the Canadian and American jurisprudence in the area of magazines is interesting, a more informative area of comparison is cable television regulation. ${ }^{143}$ In 1992, Congress

137. Id. at 256 (majority opinion). The Court, however, held that even if a newspaper faced no additional costs and would not have been forced to forego printing something else, the statute would nevertheless be unconstitutional "because of its intrusion into the function of editors." Id. at 258 .

138. 460 U.S. 575 (1983).

139. Id. at 585 .

140. Id. at 592 (emphasis added).

141. See supra note 42 and accompanying text.

142. Tomillo, 418 U.S. at $255-56$ (quoting Pittshurgh Press Co. v. Pittsburgh Comm'n on Human Relations, 413 U.S. 376, 400 (1973) (Stewart, J., dissenting)).

143. In the television broadcast medium, the U.S. Supreme Court has permitted Congress to make content-based regulations that have the purpose of increasing the diversity of views available. In Red Lion Broadcasting Co. v. FCC, the Court held that the FCC's "fairness doctrine," some aspects of which were similar to the "right-of-reply" rules in Tornillo, was constitutionally permissible. 395 U.S. 367, 394 (1969). The Court held that the FCC rules were justified by the scarcity of available broadcast frequencies. Because of the limited number of broadcasters that could occupy the broadcasting spectrum, the government could condition its licensing decisions on assurances from broadcasters that a wide range of views would be disseminated. Id. The Court has refused to apply the scarcity rationale to other methods of television distribution. Most importantly for the purposes of this discussion, the Supreme Court has explicitly rejected the scarcity reasoning in the context of cable, stating that "cable television does not suffer from the inherent limitations that characterize the broadcast medium." Turner Broad. Sys., Inc. v. FCC, 512 U.S. 622, 639 (1994). 
passed the Cable Television Consumer Protection and Competition Act, ${ }^{144}$ which required operators of cable television systems to devote up to onethird of their channels to local broadcast television stations. This requirement is embodied in what are usually referred to as the "mustcarry" rules. ${ }^{145}$ Finding that the economic power of cable television had placed the free local broadcast television business in jeopardy, Congress concluded that mandatory carriage is necessary to preserve local broadcasting for households that do not subscribe to cable. ${ }^{146}$ The mustcarry rules are, in some ways, analogous to the "right-of-reply" rule in Tornillo. In both cases the government required a purveyor of content to permit particular speakers to express themselves using the purveyor's forum. Unlike the right-of-reply rule, however, the Supreme Court upheld the must-carry rules.

The Court in Turner Broadcasting System v. FCC (Turner I) summarized Congress's asserted rationales for the rule as follows: "(1) preserving the benefits [to nonsubscribers of cable] of free, over-the-air local broadcast television, (2) promoting the widespread dissemination of information from a multiplicity of sources, and (3) promoting fair competition in the market for television programming." ${ }^{147}$ The majority was convinced that Congress's overriding objective "was not to favor programming of a particular subject matter, viewpoint, or format, but rather to preserve access to free television programming for the 40 percent of Americans without cable." ${ }^{148}$ Accordingly, the majority held that the mustcarry rules were content-neutral. The appropriate inquiry, therefore, was whether the rules " further[] an important ... governmental interest; ... and [whether] the incidental restriction on alleged First Amendment freedoms is no greater than is essential to the furtherance of that interest." "149 The Court concluded that each of Congress's asserted rationales-including the "widespread dissemination of information from a multiplicity of sources" - was an "important governmental interest." 150 The Court remanded the case for additional fact-finding to determine whether the broadcast industry was actually under serious threat from the cable industry and whether the must-carry rules were overly intrusive in curtailing the First Amendment rights of cable providers.

Turner $I$ highlights an important difference between the Canadian and American constitutional approaches in this area. In Canada, one of the

144. Cable Television Consumer Protection and Competition Act of 1992, Pub. L. No. 102385,106 Stat. 1460 (codified in scattered sections of 47 U.S.C.).

145. Id. $\$ \$ 4-5$, 106 Stat. at 1471-81 (codified as amended at 47 U.S.C. $\$ \$ 534-535$ (1994)).

146. Id. $\S 2(\mathrm{a})(8)(\mathrm{D}),(16), 106$ Stat. at 1461-62 (codified as amended at 47 U.S.C. $\$ 521$ ).

147. 512 U.S. at 662 .

148. $I d$. at 646 .

149. Id. at 662 (quoting United States v. O'Brien, 391 U.S. 367, 377 (1968)).

150. Id. at 662-63. 
important normative reasons for protecting expression is to ensure that a diverse array of ideas is available in the public sphere. ${ }^{151}$ In the United States, the state's interest in diversity (or, using the language of the Turner I Court, " "the widest possible dissemination of information from diverse and antagonistic sources" ${ }^{152}$ ) must be balanced against the First Amendment guarantee of free speech. The U.S. decisions indicate that the state's interest in a diversity of ideas is considered an "important," but not a "compelling," interest. ${ }^{153}$ As noted above, the majority in Turner I found that Congress's interest in diversity was an important interest that could justify a purportedly content-neutral cable regulation. In Tornillo, the Florida government's interest in making available a diverse set of views in the press was not compelling enough to justify the content-based right-ofreply statute. ${ }^{154}$

In Turner I, the majority's determination of content-neutrality rested primarily on Congress's averred intent to preserve television for those who do not subscribe to cable. Congress had found that most cable providers operate a monopoly over cable service in their areas. If cable providers refused to carry broadcasters' signals, the number of households that would have access to the broadcasters' programming would decline. As fewer viewers tuned in to broadcast television, the advertising dollars that would otherwise have gone to broadcast stations would be redirected to cable television stations. Since cable providers increasingly owned or were affiliated with many of the cable stations they carried, cable providers stood to benefit from those redirected ad revenues. Thus, the majority held, the must-carry rules were not intended to differentiate on the basis of content, but to curtail the anticompetitive practices of the cable industry and to preserve television for American households that do not subscribe to cable. ${ }^{155}$

Many commentators have criticized the Turner Court's characterization of the must-carry rules. Charles Fried maintained that the majority "adopted a mistaken conception of content neutrality." 156 Another commentator elaborated, stating:

It is difficult [in light of Congress's explicitly content-based concerns in structuring the broadcast industry] to imagine that

151. See supra text accompanying note 91 .

152. 512 U.S. at 663 (quoting United States v. Midwest Video Corp., 406 U.S. 649, 668 n.27 (1972) (plurality opinion)).

153. For a content-neutral regulation to pass constitutional muster, the government's interest must be "important." Id. at 662 (quoting United States v. O'Brien, 391 U.S. 367, 377 (1968)). A content-based regulation must advance a "compelling" government interest. Minneapolis Star \& Tribune Co. v. Minn. Comm'r of Revenue, 460 U.S. 575, 585 (1983).

154. See supra text accompanying notes $130-137$.

155. Turner, 512 U.S. at 632-34.

156. Charles Fried, Perfect Freedom, Perfect Justice, 78 B.U. L. REv. 717, 745 (1998). 
Congress would justify the must-carry rules except in part on grounds that the content of local television is expected characteristically to differ from that on cable and that this different content has value. ${ }^{157}$

Another likewise found it implausible that Congress would have sought to preserve the benefits of broadcast television had it not found the content those stations disseminated to be valuable. "[U]nless there were some inherent public value to what [the broadcast] medium provides," she wrote, "there would be no purpose to government efforts to preserve a particular medium or to maintain its free availability." 158

One of the most forceful critics of the majority's decision was Justice O'Connor. ${ }^{159}$ She pointed out that the text of the Cable Act itself demonstrated that Congress wished to privilege local broadcast stations because it valued the content they disseminated. For example, in the Act, Congress extolled the virtues of public broadcast television, stating that it "provides educational and informational programming to the Nation's citizens, thereby advancing the Government's compelling interest in educating its citizens." ${ }^{160}$ It referred to public broadcast television as a "local community institution ... that provides public service programming that is responsive to the needs and interests of the local community." 161 More generally, Congress found that "[b]roadcast television stations continue to be an important source of local news and public affairs programming and other local broadcast services critical to an informed electorate." 162

Congress also asserted that it had a substantial interest in "ensuring that cable subscribers have access to local noncommercial educational stations." 163 It is difficult to imagine how Congress could have had a content-neutral interest in ensuring that cable subscribers had access to these local broadcast channels. Unlike the households that did not subscribe to cable, cable subscribers were never in danger of losing access to television programming altogether. The must-carry rules required cable providers to devote up to one-third of their channels to broadcast stations, meaning that broadcasting stations would be in some cases substituted for cable stations. Thus, for cable subscribers, the must-carry rules affected

157. C. Edwin Baker, Turner Broadcasting: Content-Based Regulation of Persons and Presses, 1994 SUP. CT. REV. 57, 60.

158. Gretchen Craft Rubin, Quid Pro Quo: What Broadcasters Really Want, 66 GEO. WASH.

L. REV. 686, 695 (1998) (book review).

159. See Turner, 512 U.S. at 674 (O'Connor, J., concurring in part and dissenting in part).

160. Cable Television Consumer Protection and Competition Act of 1992, § 2(a)(8)(A), 106 Stat. 1460,1461 .

161. Id. \& 2(a)(8)(B), 106 Stat. at 1461.

162. Id. \& 2(a)(11), 106 Stat. at 1461.

163. Id. \$2(a)(7), 106 Stat. at 1461 (emphasis added). 
what they watched, but not whether they could watch television at all. Congress's interest in ensuring that cable subscribers could access broadcast stations, therefore, seems almost certainly based on the value of the content disseminated by broadcast stations and the purported interests of cable subscribers in receiving it. ${ }^{164}$

Justice O'Connor further pointed out that in some cases the Act requires the FCC to consider content-based factors in determining whether a broadcast station should be eligible for must-carry privileges in a particular market. In particular, the Act requires the FCC to " 'afford particular attention to the value of localism by taking into account such factors as ... whether any other [eligible station] provides news coverage of issues of concern to [a] community or provides carriage or coverage of sporting and other events of interest to the community." 165 Further, in determining whether a "low-power" community station is eligible for must-carry privileges, the Act requires the FCC to ask whether the station " "would address local news and informational needs which are not being adequately served by full power television broadcast stations." 166 These grants of authority "illustrate the most obvious justification for must-carry provisions as a whole-to promote local content by safeguarding local broadcasting." 167

\section{CONGRESS's EFFORTS TO PRESERVE A VISAGE CULTUREL IN AMERICA}

The conditions that prompted Congress to enact the must-carry rules in the United States are analogous to the situation in Canada. Congress found that local television, which features community voices and perspectives, was in danger of being overrun by nonlocal television stations on cable. The problem was not that cable stations did not themselves feature a diverse set of views and perspectives. What Congress found to be missing was a particular set of ideas and experiences inherent to the content delivered by local broadcast stations. Praising local broadcast programming as the " "linchpin of localism,"” 168 Congress found that commercial broadcast television provides vital local news and public affairs programming not

164. It is possible that Congress found that broadcast stations make significant contributions to local economies that would be as valuable to local cable subscribers as noncable subscribers. Nothing in Congress's findings, however, refers to such nonspeech community impacts of broadcast stations. In contrast, and as noted above, Congress referred extensively to the value of the content disseminated by broadcast stations.

165. Turner, 512 U.S. at 677 (O'Connor, J., concurring in part and dissenting in part) (quoting 47 U.S.C. \& 534(h)(1)(C)(ii) (1988 \& Supp. IV 1992)).

166. Id. (quoting 47 U.S.C. $\$ 534(\mathrm{~h})(2)(\mathrm{B})$ ).

167. Baker, supra note 157 , at 61 .

168. H.R. REP. No. 102-628, at 56 (1992) (quoting Alfred C. Sikes, Remarks Before the International Radio and Television Society 6 (Sept. 19, 1991)). 
available on national cable stations. ${ }^{169}$ Additionally, Congress found that public broadcast stations, most of which are licensed to state and local government agencies, public colleges and universities, school districts, and other public groups, provide many "programs offering outlets for local cultural and artistic groups." ${ }^{170}$ Finally, Congress sought to protect lowpower community broadcast stations" $\mathrm{s}^{171}$ because they feature "significant amounts" of locally produced programming, including foreign-language programs for local ethnic communities. ${ }^{172}$

The Canadian pop culture industries are analogous to the local broadcast stations that Congress sought to protect. ${ }^{173}$ Canadian magazine publishers and television stations, while not obligated to do so, tend to produce more content reflecting the purported unique perspectives and experiences of Canadians in the same way that American local broadcast stations feature more content of special interest to their local communities. Congress feared that the idiosyncratic local dialogue featured on broadcast stations would be displaced by an onslaught of cable programming from the rest of the country. Similarly, the Canadian government found that the inundation of pop culture products from the much larger American market was a serious economic threat to the Canadian industry. And Congress responded in much the same way that the Canadian government chose to address the continual threat posed by non-Canadian popular culture. It would appear, therefore, that even Americans (or at least American lawmakers) occasionally find value in shaping the marketplace of ideas to include pop culture content that reflects the distinctive outlook of a community.

While the must-carry rules do not influence what Americans watch on television to the same degree that the Canadian broadcasting and cable rules influence what Canadians watch, they nevertheless significantly affect local broadcast carriage on cable. Before those rules were enacted, studies conducted by the cable industry showed that 205 cable systemsrepresenting 2.5 million subscribers-did not carry any local broadcast

169. See S. REP. NO. 102-92, at 42 (1992), reprinted in 1992 U.S.C.C.A.N. 1133, 1175; H.R. REP. NO. $102-628$, at $56,69$.

170. H.R. REP. NO. $102-628$, at 69.

171. In 2001 , there were 2200 low power broadcast stations on the air in approximately 1000 communitics in all fifty states. Richard E. Wiley, Communications Law in 2001-A New Environment: Telephone, Broadcast and Cable, in COMMUNICATIONS LAW 359, 408 (PLI Intellectual Prop. Course, Handbook Series No. G-679, 2001).

172. In the Matter of Review of the Commission's Rules Governing the Low Power Television Service, 9 F.C.C.R. 2555, 2555 (May 19, 1994).

173. I do not mean to suggest that Canadian popular culture as a whole is analogous to the idiosyncratic mores of a single local American community. To be sure, Canada is composed of many diverse communities, large and small, each with its own distinguishing characteristics and associated pop culture influences. My observation is that American local broadcast stations, like Canadian purveyors of popular culture, were perceived by the federal government as threatened by outside influences and worthy of protection. 
stations at all. ${ }^{174}$ Extrapolating from those limited studies, the Senate Committee on Commerce, Science, and Transportation estimated that 1700 cable providers had refused to carry local television stations in 3600 instances. ${ }^{175}$ The rules now require that all cable providers with more than twelve channels devote up to one-third of their total channel capacity to local commercial television stations that request carriage. ${ }^{176}$ Additionally, cable providers with more than thirty-five channels must carry at least two low-power "community" stations ${ }^{177}$ and providers with more than thirty-six channels must carry all stations within fifty miles classified as "local noncommercial educational stations." 178 As of late 1996, the must-carry rules mandated that cable stations carry 35,886 local broadcast channels nationwide. ${ }^{179}$ The must-carry rules also have a significant effect in that they require cable operators to assign a local broadcast station to the same channel number as that station uses to broadcast over the air. ${ }^{180}$ Finding that cable providers often shift the placement of local channels on their cable systems $^{181}$ and that channel position can be crucial to a broadcast station's success on a cable system, ${ }^{182}$ Congress included the channel position requirement to keep local stations in their " "prime VHF channel slots." 183

One of the arguments the United States advanced during the magazine dispute at the WTO was that the Canadian government was entitled to preserve its cultural industries through direct subsidization. What Canada was not permitted to do, the United States argued, was to use protectionist measures that restricted access of American publications to the Canadian market. ${ }^{184}$ Interestingly, that same argument could be leveled against the

174. S. REP. No. 102-92, at 43, reprinted in 1992 U.S.C.C.A.N. at 1176 .

175. Id.

176. 47 U.S.C.A. $\$ 534($ b)(1)(B) (West Supp. 2001).

177. Id. $\$ 534(\mathrm{c})(1)(\mathrm{B})$.

178. Id. $\$ 535(\mathrm{c}),(l)(2)(\mathrm{A})$. Under $\$ 535(\mathrm{e})$, however, providers need not carry stations with programming that "substantially duplicates" that of another "local noncommercial educational television station." Id. $\$ 535(\mathrm{e})$.

179. See Turner Broad. Sys., Inc. v. FCC, 520 U.S. 180, 249-50 (1997) (O'Connor, J., dissenting). Though cable operators claimed that they were already carrying about eighty-five percent of those broadcast stations, those stations are nevertheless part of those rules' First Amendment burden, because the rules prevent operators from dropping those broadcast stations later should more desirable cable stations become available. Id.; $c f$. Miami Herald Publ'g Co. v. Tomillo, 418 U.S. 241,258 (1974) (holding that a statute requiring a newspaper to publish specified matter limits speech even if publishing it does not prevent the paper from printing something else or cause it to incur additional costs).

180. 47 U.S.C. $\$ 534(b)(6)$ (1994).

181. The Senate Committee noted that 974 of the cable systems that had responded to an FCC survey had admitted that they had shifted the position of local stations in nearly 3000 instances. S. REP. NO. 102-92, at 43-44 (1992), reprinted in 1992 U.S.C.C.A.N. 1133, 1177.

182. H.R. REP. NO. 102-628, at 55 (1992).

183. Id. (quoting Cable Television: Hearings Before the Subcomm. on Telecommunications and Finance of the House Comm. on Energy and Commerce, 100th Cong. 531 (1988)).

184. Canada-Certain Measures Concerning Periodicals, Report of the Panel, supra note 29 , at $497-98$. 
must-carry rules. Congress could also have chosen to preserve the local broadcasting industry using subsidies-and this was, in fact, what Justice O'Connor suggested in Turner $I^{185}$ Like the Canadian government, however, Congress chose to implement protective rules instead, despite the greater burdens on speech those rules engendered. When the Turner case came before the Supreme Court for the second time, the majority considered the possibility of a system of subsidies as an alternative to the must-carry rules. Finding that the must-carry rules would be simpler to administer and would be less likely to require the government to make content-based determinations about specific programming, the Court held that Congress had the prerogative to implement the more restrictive constraint on speech in that case. ${ }^{186}$

It is not surprising that the American government argues forcefully for cultural free trade internationally while at the same time burdening speech to protect local culture at home. The dominant position of the United States on the global stage, coupled with the saturation of American life with American popular culture products, means that few Americans would seriously consider the presence of foreign works in the United States a serious threat to sovereignty. It took a threat to local community identity (ironically from the same American mass culture that threatens cultural industries in other countries) to smoke out the more nuanced American view that pop culture works can have a distinct value that transcends freemarket principles.

The must-carry rules thus expose the myth of the United States as a paragon of cultural free trade. President George W. Bush recently pledged to "[w]ork to ensure that provisions in trade agreements are compatible with important domestic policy objectives." 187 Consequently, the divergence between America's international position on culture and its domestic protective measures ought to be reconciled. When the next Canadian cultural controversy arises, rather than adopting the extreme position that pop culture works are merely ordinary commodities, ${ }^{188}$ the

185. She argued:

The interest in localism, either in the dissemination of opinions held by the listeners' neighbors or in the reporting of events that have to do with the local community, . . is a legitimate interest, nerhans even an important one-certainly the goyernment can foster it by, for instance, providing subsidies from the public fisc-but it does not rise to the level necessary to justify content-based speech restrictions.

Turner Broad. Sys., Inc. v. FCC, 512 U.S. 622, 680 (1994) (O'Connor, J., concurring in part and dissenting in part).

186. Turner Broad. Sys., Inc. v. FCC, 520 U.S. 180, 222 (1997).

187. OfFICE OF THE U.S. TRADE REPRESENTATIVE, 2001 INTERNational TRADE LEGISLATIVE AGENDA 5 (2001), http://www.ustr.gov/agenda.pdf.

188. During the most recent dispute over Canada's protective rules on periodicals, U.S. Trade Representative Charlene Barshefsky threatened to retaliate "by withdrawing benefits of equivalent commercial effect." Press Release, Office of the U.S. Trade Representative, United 
U.S. Trade Representative should consider the more subtle view Congress affirmed when it used pop culture discrimination to preserve a visage culturel in local communities. ${ }^{189}$ Given Congress's appreciation of the special qualities of pop culture, the USTR should be more willing to understand and accommodate the efforts of other nations to preserve their own cultural industries.

\section{CONCLUSION}

This Note began with three quotations. The first two were extreme Canadian and American views on the meaning and importance of popular culture. Margaret Atwood's rhetoric is an exaggerated account of the Canadian preoccupation with fostering and maintaining an identity that is self-consciously not American. For Canadians, works of popular culture, which allow for the exchange of distinctly Canadian views and perspectives, are integral to building a vibrant Canadian community and maintaining that non-American identity. The Canadian perspective is consistent with the Canadian freedom of expression jurisprudence, which has as one of its core values the promotion of a diversity of ideas in the public sphere. I argued that the Canadian Supreme Court would likely uphold the protective cultural measures currently in place for magazines and cable television for the same reason the Court would uphold a Quebec sign law that required French to be the "markedly predominant" language displayed. Since the unfettered importation of foreign pop culture works would seriously threaten Canadian cultural industries, the Court-in the interest of diversity-would uphold the Canadian government's attempts to preserve a place for Canadian works and ideas in a market where foreign works predominate.

The second quotation, from Mark Fowler of the FCC, is at the same time accurate and misleading. By comparing televisions to toasters, Fowler was not articulating the position that expressive commodities are no different from ordinary consumer goods. After all, if the government wished to do so, it could regulate the market for toasters extensively with no constitutional ramifications. This was not the FCC's position at the time; rather than ratcheting up its level of regulation, it was actively reducing regulatory constraints on broadcasting and other communications. Instead,

States To Take Trade Action if Canada Enacts Magazine Legislation (Oct. 30, 1998), http://www.ustr.gov/releases/1998/11/98-96.pdf.

189. The USTR is required by statute to consider congressional policies when developing the executive position in trade negotiations. One formal mechanism for obtaining "advice on the development of trade policy" is the appointment of five members of the House and five members of the Senate as "congressional advisers [to the President and the USTR] on trade policy and negotiations." 19 U.S.C. $\$ 2211$ (a)(1) (1994). 
Fowler's comment stands for the underlying American belief that expressive works belong to a special kind of market, but a market all the same: Holmes's marketplace of ideas. Current First Amendment doctrine holds that expressive works are a special type of commodity that the government may not regulate on the basis of content without a compelling reason. Influenced by that First Amendment optic, U.S. Trade Representatives view Canadian protective measures as impermissible restraints on trade in a market where Americans view restrictions to be particularly inappropriate. Not surprisingly, the American constitutional doctrine in this area tracks America's international position-the interest in ensuring access to a wide range of views from diverse and antagonistic sources is not compelling enough to justify a content-based restriction on expression.

Despite that overarching U.S. position, I observed that when works of popular culture in America's local communities are threatened as Canadian cultural products are endangered by American imports, the American position appears to change. Finding that "[t]here is a substantial government and First Amendment interest in promoting a diversity of views provided through multiple technology media" (the third quotation), Congress enacted protective must-carry rules. And those rules are in many ways analogous to the Canadian protective regulations that the United States so consistently criticizes. The must-carry rules suggest that Congress does not conceive of pop culture works as mere ordinary goods. Therefore, instead of arguing for cultural free trade on the international stage while Congress deviates from those same free-market principles to protect the works that animate local communities, the U.S. Trade Representative should acknowledge that Americans appreciate the special value of a community's visage culturel after all. Hopefully that perspective will enter the discussion when the next Canadian cultural controversy arises. 
$* * *$

Imaged with the Permission of Yale Law Journal 